\title{
Migration, Identities and Human Rights Representation in African Literature: Re -Reading Adichie's Americanah
}

\author{
Angela Ngozi Dick \\ Correspondence: Angela Ngozi Dick, Department of English and Literary Studies, Veritas University Abuja, Nigeria.
}

Received: July 9, 2019

doi:10.5430/elr.v8n3p21

\author{
Accepted: August 25, 2019 \\ Online Published: August 30, 2019 \\ URL: https://doi.org/10.5430/elr.v8n3p21
}

\begin{abstract}
Adichie's Americanah is one of the African novels whose characters and settings traverse cultures. The author herself is a product of trans-cultural education and uses this medium to draw global attention to the difficulty faced by migrants. Most of the African diaspora characters work hard to gain visibility in a culture that obliterates the personality of migrants irrespective of gender and academic achievements. Adichie's representation of the characters captures much of the realities told by migrants navigating and negotiating life outside their countries of origin. Through personal will to get a better life outside their home countries, the characters engage in some self-effacing work to acquire permanent residency so that they can return home for acclaim. The author uses local colour and synaesthesia to remind the characters of their roots and the rhetorics of scatology to portray the hostility of the receiving country.
\end{abstract}

Keywords: migration, identity, human right

\section{Introduction}

The topic of migration and asylum came to prominence in 2015 (Pierigh, 2017) two years after the publication of Adichie's Americanah. Millions of people are affected across the world. Migrants are basically itenerant until they attain equilibrium. The migrants feel, see or smell things differently based on their emotional construct thus, foregrounding the concept of synaesthesia. This is because they are away from fluid, known spaces, and not rigid spaces. Synaesthesia is a literary construct used by writers to link ideas, characters or settings to the five human senses to accentuate a subject matter. Udenta (2018), problematizes dirt and smell imageries as "physical revelation of the depth of dehumanization and a categorical testament of the evacuation of the moral spirit of postcoloniality expressed in the conducts of its social victims" (p.147). It can be added that Udenta's work is a critic of post Uhuru in Kenya especially, and Africa. In this article, migration, identity and human rights are the elements that define the actions and reactions of the characters within a particular space with formidable, rigid differentiating markers.

During the Elizabethan Age, William Shakespeare, using one of the characters named Iago in Othello, describes jealousy as "the green-eyed monster which doth mock the meat it feeds on" (Acts 3. Scene 3). Jealousy is an emotional state not an animate creature with one of the five senses. It is so used to caution about the malevolence of jealousy. Alghieri Dante writing during the European Renaissance in The Divine Comedydescribes the deeps of hell in Canto 1 as a place where "the sun is silent" (qtd. Holt, Rinehart \& Winston 1993, pp. 742-749), coalescing the visual and auditory senses. In African American Literature, writers like Langston Hughes make profuse use of synaesthesia to bring to the fore the complex problem of being black in a white dominated American society during the Harlem Renaissance. In his popular poem entitled "Harlem", certain expressions were used to depict the contrasting reactions of blacks and whites during that period. For example, "Does it stink like rotten meat; Or crust and sugar over ....; like a syrupy sweet". The expressions inundating the first page of Adichie'sAmericana (2013), provoke the olfactory sense introducing the disadvantaged position of the immigrant Nigerian woman called Ifemelu ready to go back to her country after thirteen years of life in diaspora (p.3).

\section{Determinants of Migration in Americanah}

All creatures migrate because of change in the environment, food scarcity or for perpetuating the species. However, human migration, according to the United Nations Human Rights Commission (2002): “ is a systemic condition driven by economic under- development, severe social fragmentation, weak state, migration policies that shapeinteraction between sending and receiving states, and colonial ties" (pp.4-8). It is worthy of note that Everett Lee's Push-Pull Theory (1966,) has been the basis of the work on human migration in which he proposed that:place 
of origin, place of destination, intervening obstacles and personal factors lead to spatial mobility of population (qtd. in Rashid Faridi's blog ). The driving force of immigration in Americanah is indexed on micro theory on migration in which economic under-development pushes the characters to migrate to the receiving countries (Americanah pp.91, 99). While Ginika's father got a teaching job in Missouri (p.65), Ifemelu's father is wounded by scarce finance and powerlessness at home. Ifemelu speaks of her father in nostalgia:

Looking at him as he sat on the sofa she thought how much he looked like what he was, a man full of blanched longings, a middle brow civil servant who wanted a life different from what he had, who had longed for more education than he was able to get. He talked often of how he could not go to university because he had to find a job to support his siblings, and how people he was cleverer than in secondary school now had doctorates (p.47).

However, the college friends are challenged by the disruption of academic calendar, the need to earn scholarships and adventure (pp.91, 99), or escape from co-wife assault, like Aunty Uju (pp. 86-87).This section has discussed why migrants leave their homes for foreign countries, the next sub-section will dwell on the psychological effects of opposing forces on the lives of the migrants.

\section{Identity and Emotion of the Migrants}

Emotion derives from environment, relationships, degree of pleasure or displeasure. Insights from Hockenbury and Hockenbury (2007) show that: "emotion is a complex psychological state that involves three distinct components: a subjective experience, a physiological response and a behavioural or expressive response" (www. verywellmind.com). Migration tends to deposit disenchantment, synaesthesia disorder and depression on the migrants. For example, Ifemelu keeps smelling the different cities she has traversed to confer a measure of statistical preference for her residence:

Princeton in summer smelled of nothing .... Philadelphia had the musty scent of history. New Haven smelt of neglect. Baltimore smelled of brine, and Brooklyn of sun-warmed garbage. But Princeton had no smell (Americanah p.3).

Pleasant smels can improve mood, sense of wellbeing, engender positive image, help to deal with specific memories. This is the contention of some scholars as reported by Social Issues Report entitled "The Smell Report" (sirc.org). Thus, specific but personalized smells remind Ifemelu of home and enables her adjust to the new environment. Although her initial joy is dampened by unsuccessful job search, gradually, she slips into perceptual disorder driven by long search for job and decent accommodation to enable her cope with the demands of academics notwithstanding that: "school in America is easy, assignments sent in by e-mail ...professors willing to give make-up tests" (Americanah p.132).Her experience with the coach (p.156) has a reductionist effect on her personal identity, disconnects her from relationships, especially Obinze, a loss that gnaws at her soul until she re-unites with Obinze in Nigeria towards the end of the novel. The following excerpt attests to that:

She woke up torpid each morning, slowed by sadness, frightened by the endless stretch of day that lay ahead. Everything had thickened. She was swallowed, lost in viscous haze, shrouded in a soup of nothingness. Between her and what she should feel, there was a gap. She cared about nothing. She wanted to care but she no longer knew how it had slipped from her memory, the ability to care (p.156).

Moreover, every other relationships she contracts (Blaine, p. 176 and Curt p. 191) were coloured by race and skin tincture.This writer hastens to add that Curt actualized Ifemelu's search for permanent residency documents and a decent job (pp.191-200).

On the other hand Aunty Uju is saddled with passing her medical examination, and having a father figure for her son, Dike. Having passed her exam, she settles with Bartholomew but he is not responsible enough to be surrogate father for Dike. All these shrink her personal identity personal hygiene. She begins to wear irreverent dresses (pp. 108-109). In the preface to Fanon's The Wretched of the Earth (2008), Jean Paul Satre admits that it is not impossible for neocolonialism to change a man into an animal (p.14) Bartholomew, on his own part has been consumed by personality imbalance, bringing in its trail, loss of communication with his family in Nigeria, cynicism and sponging from women like Uju. Feeling a sense of stagnation on all fronts, Aunty Uju bolts away from Bartholomew and starts a new life with Dike in a condo house at Willow (Americanah pp. 217-219). The immigration laws of the receiving nation dwarf and warp the identities of the migrants.

Hostility of Receiving Country and Human Rights 
This section will rely on United Nations International Covenant on Civil and Political Rights: First Option Protocol 1976, Second Option Protocol 1989. Among others the protocols promote freedom of movement, equality before the law, condemns degrading treatment or punishment, racial or religious hatred (un.org). For Ifemelu, her English Language competence is tasted in the office of the International Student by Cristina Tomas (Americanah p. 133). The reductionist effect on the character is narrated thus:

In that strained, still second when her eyes met Cristina Tomas before she took the forms, she shrank like a dried leaf. She had spoken English all her life, led the debating society in secondary school, and always thought the American twang inchoate; she should not have cowered and shrunk, but she did. And in the following weeks, as autumn's coolness descended, she began to practice an American accent (pp.133-135).

The name, Cristina Tomas is repeated four times in one paragraph, accentuating her mortification even though the story is inserted as a flashback. On the contrary Dike is not emotionally old enough to absorb the onslaught of racial labeling and accusation of hacking into the school computer in addition to drug use (p.349). His suicide bid is stalled by providence. Dike had: "swallowed a whole bottle of Tylenol [together with] anti nausea so that the medicine would stay in his stomach" (p.365).The rights of Ifemelu are violated on linguistic consideration by Cristina Tomas, while Dike's rights are violated based on suspicion or mistrust. Beyond language and suspicion, scatology is enlisted in violating the rights of other migrants like Obinze.

The setting of Americanah in London engages the rhetorics of scatology. In the medical sciences, scatology is the diagnosis of faeces while in Literature it affects the behavior of characters. In the words of Persels and Russell (2004), scatological rhetoricsis: "the representation of the processand product of the elimination of the body's waste (faeces, urine, flatus, phlegm, vomitus)", (p.2). According to them, human waste has the power to make us "blush, provoke shame and embarrassment"(p.2).Lethbridge, on the other hand, argues that scatology: "works through inversion and thus as subversion - bottom comes top, high turns low, back becomes front... (pp. xii; 292). This gains significance for Obinze working as a toilet cleaner to earn enough to get a permanent visa, having come in with a short term visa. It is deserving to note that Obinze is the only child of a professor of English Studies in University of Nigeria, Nsukka, associated with luxury and decency. One evening he discovers a feat of human subjugation: "a mound of shit on the toilet lid... carefully arranged and the exact spot had been measured"(Americanah, pp.236-237). He resigns to retain his personality. Another telling moment in which Obinze's personality is threatened is at the marriage registry. Moments before the conclusion of that fake marriage, he is apprehended by immigration officials. He chooses repatriation instead of litigation. Obinze is portrayed as a stronger migrant ready to return to his home country instead of being consumed by lack of identity in diaspora.

\section{Non Fictional Migrants}

Beyond migration narrative in Americanah, the travails of non fictional migrants have become a global concern. From Mexico and the Americas, Middle East, Sub-Sahara Africa and North Africa, people are fleeing their countries to escape extra -judicial deaths, hunger, poverty, war and prolonged insecurity challenges. The European Union is working hard to reduce the influx of migrants across the Mediterranean. The United Nations Human Rights Commission is overwhelmed. Human will to survive has continued to make people travel notwithstanding oddities and fatalities deriving from such movements(ALJAZERRA). The United Nations and other heads of nations need to articulate new models of democracy that will keep people in their countries of origin, develop new entrepreneurial space like landscape engineering, food or nutritional engineering, recycling waste products among others, that will make people use their hands and heads to support national and world economy. The world may minimize migration but cannot stop it.

\section{Conclusion}

Adichie's Americana is not an exercise in literary rhetorics but an incursion into human existence and existentialism. The literary men and women portray global verisimilitude, since the end of colonialism and new transport systems that shorten journeys.Children like Dike are not spared labeling in the diaspora.Linguistic intimidation, racial, skin or cultural misrepresentations are used to marginalize the migrants. The migrant characters are treated with less human dignity. Race and colour engaging simultaneously construct intimidation and growing self degradation on the psyche of the migrants. At home Obinze becomes a wealthy businessman, owning numerous hectres of land. Okwudiba and Ifemelu also return to Nigeria with prospects of good jobs. While in diaspora the author continues to identify the characters with their native names except when these characters bear pseudonyms for interviews and to retain their jobs (pp. 120-121). The couching of migrant characters who return to work in their country of origin is cheering. After all, east or west, home is best. 


\section{References}

Adichie, C.N. (2013). Americanah. Lagos: Kachifo.

Alghieri, D.The divine comedy in Holt, Rinehart \& Winston Inc. (1993).World literature.Chicago: Harcourt Brace Jovanovich.pp. 742-749.

Aljazeera. (Tuesday, $16^{\text {th }}$ July 2019). Central Americans fleeing poverty and crime.Newshour .03.41.

Fanon, F. (1963).The wretched of the earth.(2008 edition).England : Penguin.

Faridi, R.(2013). Migration theories: Lee's push pull theory. Rashid's Blog: An educational portal.https://rashidfaridi .com/2018/04/05>Retrieved .29 ${ }^{\mathrm{TH}}$ June, 2013.

Hockenbury, D., \& Hockenbury, S.E.(2007). Emotions and types of emotional responses.Dotdash publishing family, 2019.www.verywellmind.com

Hughes, L. (1959). Selected poems of Langston Hughes. $6^{\text {th }}$ edition.New York: Vintage Classics.

Lethbridge, S.,\& Peter, J. S. (2014). Between two stools: Scatology and its representations in English Literature, Chaucer to Swift .The Spencer review43.3.6 Winter 2014,<English. Com.ac.uk> Accessed6 ${ }^{\text {th }}$, July2019.

Persels, J., \& .Russell, J. G. (2004). Scatology, the last taboo: Introduction to fecal matters in early modern literature and art. University of Nebraska .pp2-6<digitalcommons.unl.edu/modlangfacub>Accessed July $6^{\text {th }} 2019$.

Pierigh, F. (2017).Changing the narrative: Media representation of refugees and migrants in Europe.<refugeesreporting.eu/report> Accessed $7^{\text {th }}$ July 2019.

Social Issues Report entitled. "The Smell Report”.<sirc.org> Accessed August 24, 2019.

The Complete works of William Shakespeare. New Lanark: Geddes \& Grosset. 2001, pp.477-497.

Udenta , O.O. (2018). Art, society and identity: Essays on African Literature. Ibadan: Kraft Books Limited.

United Nations Human Rights Commission (2002).<un.org/humanright> Accessed July 4th, 2019. 